\title{
The Medical Insurance for a New Generation: a viable answer for the health needs of Mexican children
}

\author{
Onofre Muñoz-Hernández, MD, MSc,, (1) Salomón Chertorivski-Woldenberg, MPP, (2) \\ Gabriel Cortés-Gallo, MD, ${ }^{(3)}$ Ricardo Pérez-Cuevas, MD, MSc, DrSc. ${ }^{(4,5)}$
}

\author{
Muñoz-Hernández O, Chertorivski-Woldenberg S, \\ Cortés-Gallo G, Pérez-Cuevas R. \\ The Medical Insurance for a New Generation: \\ a viable answer for the health needs of Mexican children. \\ Salud Publica Mex 20I 2;54 suppl I:S3-SIO.
}

\begin{abstract}
Objective. To describe the Medical Insurance for a New Generation (SMNG) as key public policy aimed at improving health care services for children under the age of five years in Mexico. Materials and methods. This paper analyzes interrelated aspects of public policies to provide health care to Mexican children: a) the demographic and health status of children, with emphasis on the wide disparities between children of varying demographics; b) the relationship of the main functions of a health care system: financing, equity, access and quality, with the provision of health care for children; c) the architecture of the Medical Insurance for a New Generation. Conclusion. SMNG is a program that can be instrumental in lowering infant mortality and alleviating the burden of families to care for sick children by improving access, quality of care and equity.
\end{abstract}

Key words: health systems; infant mortality; health policy; Mexico
Muñoz-Hernández $\mathrm{O}$, Chertorivski-Woldenberg S, Cortés-Gallo G, Pérez-Cuevas R.

Seguro Médico para una Nueva Generación: una respuesta viable a las necesidades de salud de la niñez mexicana. Salud Publica Mex 20I2;54 supI I:S3-SIO.

\section{Resumen}

Objetivo. Describir la importancia del Seguro Médico para una Nueva Generación (SMNG) como un elemento clave de las políticas públicas mexicanas destinadas a mejorar los servicios de salud para los niños menores de cinco años. Material y métodos. Este artículo analiza aspectos interrelacionados con la salud de los niños mexicanos: a) las disparidades del estado de salud entre los niños con distintas características demográficas, b) la relación de las funciones del sistema de salud: finaciamiento, equidad, acceso y calidad, con la provisión de servicios de salud para los niños, c) El diseño del Seguro Médico para una Nueva Generación como herramienta para disminuir las brechas de desigualdad en la niñez mexicana. Conclusión. El SMNG es un programa cuyo principal objetivo es fortalecer los servicios de salud desde el lado de la demanda. SMNG puede contribuir a reducir la morbilidad y mortalidad en los menores de cinco años y aliviar la carga de las familias para el cuidado de sus niños enfermos, mejorando el acceso, la calidad de los servicios de salud y la equidad.

Palabras clave: sistemas de salud; mortalidad infantil; mortalidad en menores de cinco años; políticas de salud; México

(I) Dirección de Investigación, Hospital Infantil de México Federico Gómez. México DF.

(2) Comisión Nacional del Sistema de Protección Social en Salud. México DF.

(3) Dirección General Adjunta del Seguro Médico para una Nueva Generación. México DF.

(4) Centro de Estudios Económicos y Sociales en Salud, Hospital Infantil de México Federico Gómez. México DF.

(5) Unidad de Investigación Epidemiológica y en Servicios de Salud, Centro Médico Nacional Siglo XXI, Instituto Mexicano del Seguro Social. México DF. 
$\mathrm{T}$ he health status of children under the age of five reflects the overall social conditions of the families, and the effectiveness of a country's health and social programs. ${ }^{1}$ Mexico is working to keep up with the $4^{\text {th }}$ Millenium Development Goal of reducing child mortality by two thirds in the year 2015. The country has experienced significant progress in reducing children's malnutrition, morbidity and mortality. The results are not entirely satisfactory, and the government has recognized the need to implement policies to better ensure children's health care. ${ }^{2}$

This paper aims to support the assumption that the Medical Insurance for a New Generation (Seguro Médico para una Nueva Generación, SMNG) is a viable health policy tool to tackle the inequities and reduce morbidity and mortality in Mexican children. It addresses the interrelated aspects that shape current health care public policies to provide health care to Mexican children. First, we analyze the health status and health needs of Mexican children. The focus is on the wide disparities that exist among them and the consequences of poor health in the short- and long-terms. The analysis includes nutritional status issues, such as malnutrition, overweight/obesity and anemia; it also involves the examination of infectious diseases that under-fives experience. Second, we address how the main functions of a health care system work together: financing, equity, access and quality to provide health care for children. Third, we describe the architecture of the Medical Insurance for a New Generation to support the assumption that mobilizing additional financial resources for health care services and providing financial protection improves the supply side, ad becomes a practical health policy tool to tackle the inequities that exist among Mexican children.

\section{The health status of children in Mexico}

Demographic conditions

Mexico is a mosaic of demographic and epidemiological conditions that feature substantial disparities in health, education, housing and employment opportunities. These disparities have a negative effect on the health status of Mexican children. To bridge the gap and reduce inequities, the Mexican government has launched a significant number of social and health programs.

According to the 2010 Census of Population and Household, there were 10528322 children between the ages of 0 and 4 years in 2005, accounting for $9.3 \%$ of the 112336538 inhabitants of Mexico population. ${ }^{3}$ The life expectancy in Mexico is 76.6 years (men 74.2, women 79.1), 2 to 3 years below the average of the Organization for Economic Cooperation and Development (OECD) member countries. The differences in life expectancy at birth come mostly from premature mortality. ${ }^{4}$

The United Nations Children's Fund analyzes inequity in the rights of children in three key aspects: the right to live, the right to grow healthy and well nourished, and the right to be educated. These aspects are evaluated through an index where 0 is the lowest and 10 the highest. The Mexican state of Guerrero scores the lowest (2.9), while the state of Nuevo Leon scores the highest (8.1). This means that a child born in Guerrero has fewer opportunities to live, grow healthy and be educated than a child born in Nuevo Leon. ${ }^{5}$

Mexico has four times the average infant mortality rate of developed countries. In 2000, there were 23 infant deaths (children under 12 months) per 1000 live births, while the average of infant deaths of OECD member countries was 6.5 per 1000 live births. ${ }^{6}$ Approximately $40 \%$ of infant deaths happen during the neonatal period. In 2010, the rate is 9.6 deaths per 1000 live births. The rate of infant mortality is 14.2 per 1000 and the rate of preschool children is 16.7 per $1000 .^{7}$ Neonatal mortality represents the risk of death or the survival expectancies of newborns.

\section{Nutritional status of Mexican children}

The nutritional status of children is key for their growth and development and has a definitive influence in the trajectory of functional health status in adulthood. ${ }^{8}$ Malnourished children have poor physical and cognitive development and lower resistance to illness. In a malnourished child, the illness will slow his growth and might progress to more severe forms causing disability and death. ${ }^{9}$ The short height of stunted children shows the cumulative effect of chronic malnutrition.

Several surveys conducted in Mexico have reported the figures of malnutrition throughout time. ${ }^{10,11}$ Table I shows that malnutrition has decreased, but persists, thus representing the actual conditions of the vulnerable population.

Overweight is a growing problem in Mexican children. The proportion of children who are overweight or obese is increasing. ${ }^{12,13}$ A person who is overweight or obese is at increased risk of diabetes and hypertension. ${ }^{14,15}$ The 2006 National Health and Nutrition Survey reported a prevalence of $5 \%$ of overweight and obesity in preschool children. Another study carried out in children aged 2 years showed that the prevalence of overweight was $4.4 \%$ and obesity $2.2 \%$ among children living in urban areas, while among rural two-year-olds, the prevalence of overweight was 6.7 and obesity $5.7 \% .{ }^{16}$ The increasing magnitude of this problem among children and its poten- 
tial long-term consequences make necessary to reinforce preventive activities, among which nutritional education, promotion of physical exercise, and prevention are key elements. $^{17}$

\section{Anemia}

Anemia is a nutritional disorder mainly due to iron deficiency. Children who suffer from anemia experience developmental delays in motor function, language, cognitive capabilities learning capacities and poor school performance. Furthermore, the immunological responses are also decreased. ${ }^{18,19}$ Three nation-wide surveys have stressed the magnitude of this problem. Table II shows the prevalence of anemia in these surveys.

These findings show that the prevalence of anemia is decreasing slowly, although a significant percentage of the population continues suffering from this condition. The reduction of anemia is in part due to the effective-

\section{Table I}

NUtRITIONAL STATUS OF CHILDREN UNDER 5 years in MeXico

\begin{tabular}{lccc} 
Nutritional & $\begin{array}{c}\text { I999 National } \\
\text { Status } \\
\text { Nutrition* } \\
\%\end{array}$ & $\begin{array}{c}2006 \text { National } \\
\text { Survey of } \\
\text { Health and } \\
\text { Nutrition* } \\
\%\end{array}$ & $\begin{array}{c}\text { IMSS } \\
\text { National Survey of } \\
\text { Coverage 2006 } \\
\%\end{array}$ \\
Malnutrition & 7.5 & 5 & 5.6 \\
\hline Wasting & 2.0 & 1.6 & ND \\
\hline Stunting & 17.7 & 12.7 & 14.9 \\
Sources: & & \\
* Encuesta Nacional de Nutrición 1999 \\
₹ Encuesta Nacional de Salud y Nutrición 2006 \\
§ Encuesta Nacional de Coberturas IMSS \\
\end{tabular}

Table II

Prevalence of anemia among Mexican Children

\begin{tabular}{lccc} 
& $\begin{array}{c}\text { I999 National } \\
\text { Survey of } \\
\text { Nutrition* } \\
\%\end{array}$ & $\begin{array}{c}\text { 2006 National } \\
\text { Survey of Health } \\
\text { and Nutrition } \\
\%\end{array}$ & $\begin{array}{c}\text { IMSS } \\
\text { National Survey of } \\
\text { Coverage 2006 } \\
\%\end{array}$ \\
$\begin{array}{l}\text { Children 12-23 } \\
\text { months of age }\end{array}$ & 48.8 & 37.8 & 30.1 \\
\hline $\begin{array}{l}\text { Children } 5 \\
\text { years old }\end{array}$ & 27.2 & 23.0 & 19.4 \\
$\begin{array}{l}\text { Sources: } \\
\text { * Encuesta Nacional de Nutrición I999 }\end{array}$ \\
₹ Encuesta Nacional de Salud y Nutrición 2006 \\
§ Encuesta Nacional de Coberturas IMSS
\end{tabular}

ness of different social programs, such as Oportunidades and the routine intervention of the health services that provide iron supplements to both, children and pregnant women.

\section{Infectious diseases}

Infectious diseases are still highly prevalent in children, particularly acute diarrhea and respiratory infections. The complications of these diseases (eg: dehydration and pneumonia) are the main causes of deaths among preschool children.

Diarrhea is strongly related to poverty and poor sanitary conditions. Its negative impact is mitigated with proper household treatment and timely healthcare, which in turn depends on efficient access to a medical treatment facility and personnel. The consequences of the number and severity of diarrhea episodes are measurable in the linear growth of the child and in decreased cognitive and physical functions. ${ }^{20}$

The 2006 National Health and Nutrition Survey (ENSANUT 2006) reported that the prevalence of diarrhea in under-fives was $12.9 \%$, and pointed out important regional differences. The state with the highest prevalence was Chiapas $(21.0 \%)$ and the lowest was Zacatecas (5.9\%). The Ministry of Health $(\mathrm{MoH})$ in Mexico has implemented a significant number of interventions and programs to tackle this public health problem including provision of oral rehydration salts, educational interventions aimed at mothers to provide proper homecare, promotion of exclusive breastfeeding for infants aged 0-6 months, identification of warning signs to seek timely medical care, and provision of vaccines. The rotavirus vaccine was introduced in Mexico in several phases. In 2006 the vaccine was introduced to impoverished regions of selected states, then, in 2007 it was made available to all children born after February 1st, 2007. The vaccine has been beneficial; its introduction has been associated to a significant decline in diarrhea-related deaths ${ }^{21}$ and its cost-effectiveness has been demonstrated..$^{22}$ From the provider's perspective, development of clinical guidelines, training and updating courses, and provision of necessary supplies have been implemented continuously.

Acute respiratory infections (ARI) are the most prevalent diseases in children under five years. The average child experiences three episodes per year. Children living in poor sanitary conditions, with restricted access to medical care and whose families are unable to afford complete courses of antibiotic treatment are at higher risk of developing complications that increase the risk of death. The basic interventions to decrease the death toll due to lower respiratory infections are: a) proper case 
management, which includes evidence-based guidelines and proper supply of medications, particularly antibiotics; b) vaccines against $\mathrm{HiB}$, pneumococcus and influenza; in addition, vaccines for diphtheria, measles and pertussis have had a positive impact; c) improvement in children's nutritional status; and, d) hygienic environment. ${ }^{23}$ ENSANUT 2006 reported that the prevalence of ARI in children was 50\% and asserted that a significant number of complications and deaths due to ARI could be averted if the mother knew the warning signs, and knew to look for medical care. The survey showed that a low percentage of mothers knew what symptoms to look for, and stressed the need to further educational activities at a community level.

\section{Key objectives of health systems}

A health system is defined as the set of activities whose purpose is to promote, restore or maintain health. ${ }^{24}$ In congruence with this definition, the Commission of Social Determinants on Health ${ }^{25}$ stated that: "The development of a society, rich or poor, can be judged by the quality of its population's health, how fairly health is distributed across the social spectrum, and the degree of protection provided from disadvantage as a result of ill-health." The architecture of the Mexican healthcare system is complex and, in the way in which it is currently designed, does not provide fair distribution of services to the population. A growing body of literature is critical about the characteristics of the Mexican health care system and the resultant consequences for the society. ${ }^{26}$ Taking the perspective of children's health needs, we will analyze four key aspects of a well-functioning healthcare system: financing, equity, access and quality.

\section{Financing}

Financing makes possible for all individuals to have access to health care (public health and personal services). That is made possible through raising, pooling and allocating the revenues to purchase healthcare.

The Mexican healthcare system is unfairly financed in a way that does not ensure financial protection for everyone. ${ }^{27}$ A number of circumstances accounted for this situation. Approximately half of the country's population was not affiliated with social security services. This demonstrates that households face the risk and uncertainty of not being able to afford medical care in the event that one of its members gets sick. Furthermore, it demonstrates large out-of-pocket expenditures for a healthcare system that still presents a significant percentage of the population with catastrophically high expenditures. ${ }^{28}$
Equity

Equity in health can be defined as "the absence of systematic disparities in health (or in the major social determinants of health) between social groups who have different levels of underlying social advantage/ disadvantage - that is, different positions in a social hierarchy." Equity should be measurable, and, hence, accountable for actions at policy and programmatic levels. ${ }^{29}$

Equity is among the top challenges in Mexico because of the wide differences in the health status of various population groups, in the access to health services, and in healthcare financing. The healthcare system in Mexico is not equitable. The insurance coverage for the portion of the population without social security is regressive, and those with coverage face out-of-pocket expenditures for medical treatment, which in turn produce impoverished families. The differences in the health status of Mexican children mentioned earlier demonstrate the need to bridge the gap to reduce inequities. The fact that a child born in Chiapas has $80 \%$ more probability of dying in the first year of life than a child born in Mexico City or in a northern state such as Nuevo Leon or Coahuila clearly indicates the existing disparities. ${ }^{30}$

\section{Access}

Access has a complex framework that comprises several attributes. ${ }^{31,32}$ Access is defined as the ability of a person to receive health care services, which is a function of: a) availability of personnel and supplies; and, b) ability to pay for the services. Children aged 0-4 years comprise the group that needs and uses healthcare services most often. This includes preventive care visits and ambulatory and hospital care when necessary.

One of the main barriers for access and utilization of services is not having the financial resources. Individuals with health insurance seek medical treatment at the usual source. ${ }^{33}$ The inequities in access to medical insurance and health financing can result in catastrophic expenditures for families.

The fragmentation of the healthcare system has negatively affected access to healthcare. In response, the Mexican government has implemented a wide variety of programs to improve the access to healthcare mainly to the population that the social security services do not cover. In the late 1990s, different government programs had improved access but with little impact on quality and financing. ${ }^{34}$ Such policies were focused on implementing programs to expand coverage and provide essential or primary care services. 
Access to proper antenatal care for the pregnant woman, appropriate healthcare during delivery, high quality and appropriate referral and communication between different levels of care are key determinants of newborn health status. The program Arranque Parejo en la Vida is focused on providing information and health care to pregnant women and their newborns. ${ }^{35}$ Furthermore, economic resources, highly qualified medical personnel and technology are crucial to providing care for preterm infants, infections, and congenital malformations. The resource-constrained Mexican healthcare system severely limits this level of care.

Quality

Quality of care is defined as "the degree to which health services for individuals and populations increase the likelihood of desired health outcomes and are consistent with current professional knowledge." ${ }^{36}$

For the purposes of this paper, we used the OECD conceptual framework that was defined for the Health Care Quality Indicators Project (HCQI). ${ }^{37}$

Quality comprises several dimensions focused on effectiveness, safety and patient centeredness. These core elements increase the likelihood of desired health outcomes. Furthermore, to become operational, these dimensions and aspects related to structure, process and outcomes are mentioned briefly.

From the perspective of children's health, the HCQI only addresses vaccination rates. Its definition is as follows: Vaccination rates reflect the percentage of children at either age 1 or 2 that receives the respective vaccination in the recommended timeframe. Mexico reported $96 \%$ of children vaccinated. This percentage was above the average percentage of OECD member countries (92\%). Hungary reported the highest percentage (99.9\%) and Austria the lowest (79\%). ${ }^{38}$

To our knowledge there are few published experiences addressing quality of care for pediatric patients in Mexico. Some are related to interventions aimed at improving case management of common diseases such as diarrhea and respiratory infections in an effort to decrease childhood mortality due to the complications of these diseases. ${ }^{39,40}$

Several important health problems must be addressed under the perspective of quality of care. For example, Mexico's National Health Plan 2007-2012 declared that infant mortality rate had decreased but also stressed the differences among the Mexican states. In the municipalities with lower human development index (HDI) the infant mortality rate was 32.5 while in those with higher HDI, was 15.8. These asymmetries are due to differential access to basic services and dif- ferences in the quality of care. The Plan recognizes that $79 \%$ of infant deaths are avoidable. In addition, $60 \%$ of infant deaths occur in the neonatal period due to respiratory distress, sepsis and prematurity among others. However, there is little information about the quality of care and complications pre-term or newborn infants receive. It is critical to conduct studies aimed at ascertaining better the risk factors of death in premature newborns, and at identifying those that are avoidable by or amenable to effective interventions.

\section{System for Social Protection in Health}

The government launched the System for Social Protection in Health (Seguro Popular) in 2003 to offer subsidized, publicly provided health insurance to those within the population without social security to achieve equitable access and coverage of health services. Seguro Popular is the operational component of the health sector reform that had four key objectives: 1) to increase the public spending in health; 2) to stimulate efficient allocation; 3) to protect families from excessive health expenditures; and, 4) to transform the incentives in the system, from the supply side to the demand side. ${ }^{41}$

Priority was given to poor families, who are entitled to receive an essential package of primary and secondary care interventions that are made known to the enrollees, thus enabling them to request the services and benefits of this insurance scheme. The program is also reinforced by the Fund for Protection against Catastrophic Expenditures, which aggregates the risk of diseases that are of high cost and low prevalence and should be treated at tertiary care facilities.

Seguro Popular received strong political endorsement and the legislation assured its continuity. The financial resources for Seguro Popular have increased which in turn improve fair financing and equitable distribution of the economic resources among the states, and reduce health expenditures for poor families. For example, the 2008 National Survey of Households' Income and Expenditures (ENIGH 2008) reported that the proportion of trimester expenditures in health per decile of income decreased from $4.1 \%$ to $3.1 \%$ in all deciles between the years 2006-2008. ${ }^{42}$

\section{Medical Insurance for a New Generation}

The health of children under the age of five has improved in recent years, however, as was analyzed above, the rates of infant morbidity and mortality are still above international averages. These circumstances fueled the expansion of the benefits of Seguro Popular to children under five years of age. The Federal Government 
through the Ministry of Health launched the Medical Insurance for a New Generation in 2006.

SMNG is a health care insurance that is financed through taxes. According to the rules of operation, the SMNG main objective is to contribute to decrease impoverishment due to health causes, through universal insurance of all children born after December 2006, who are not affiliated with a social security institution.

SMNG affiliates have benefits of preventive and curative care in primary, secondary and tertiary levels of care since the moment they are registered. Health care services are provided at no charge in three streams a) package of preventive care services; b) laboratory and radiology diagnostic tests) medical care, medications and other medical supplies for specific medical conditions that can be treated in secondary and tertiary care hospitals.
SMNG is expected to boost the achievements of its parent program Seguro Popular. Figure 1 depicts the framework of SMNG: source of funds, sector, system, flow of funds, packages, providers and beneficiaries. Medical services are financially supported by three defined sources of financing for specific medical conditions. a) SMNG funds to provide health care to 128 medical conditions, mostly neonatal illnesses and pre-defined public health interventions: Public health interventions: Pneumococcal and rotavirus vaccines, infant hearing screening, cochlear implants, cold chain, metabolic screening. The Under Secretary of Prevention and Promotion of Health receives the funds that are allocated to the decentralized states Ministries of Health; $b$ ) Fund for Protection against Catastrophic Expenditures that finances high-cost, low-prevalence diseases, such as cancer; and c) Universal Catalog of Health Services that comprises

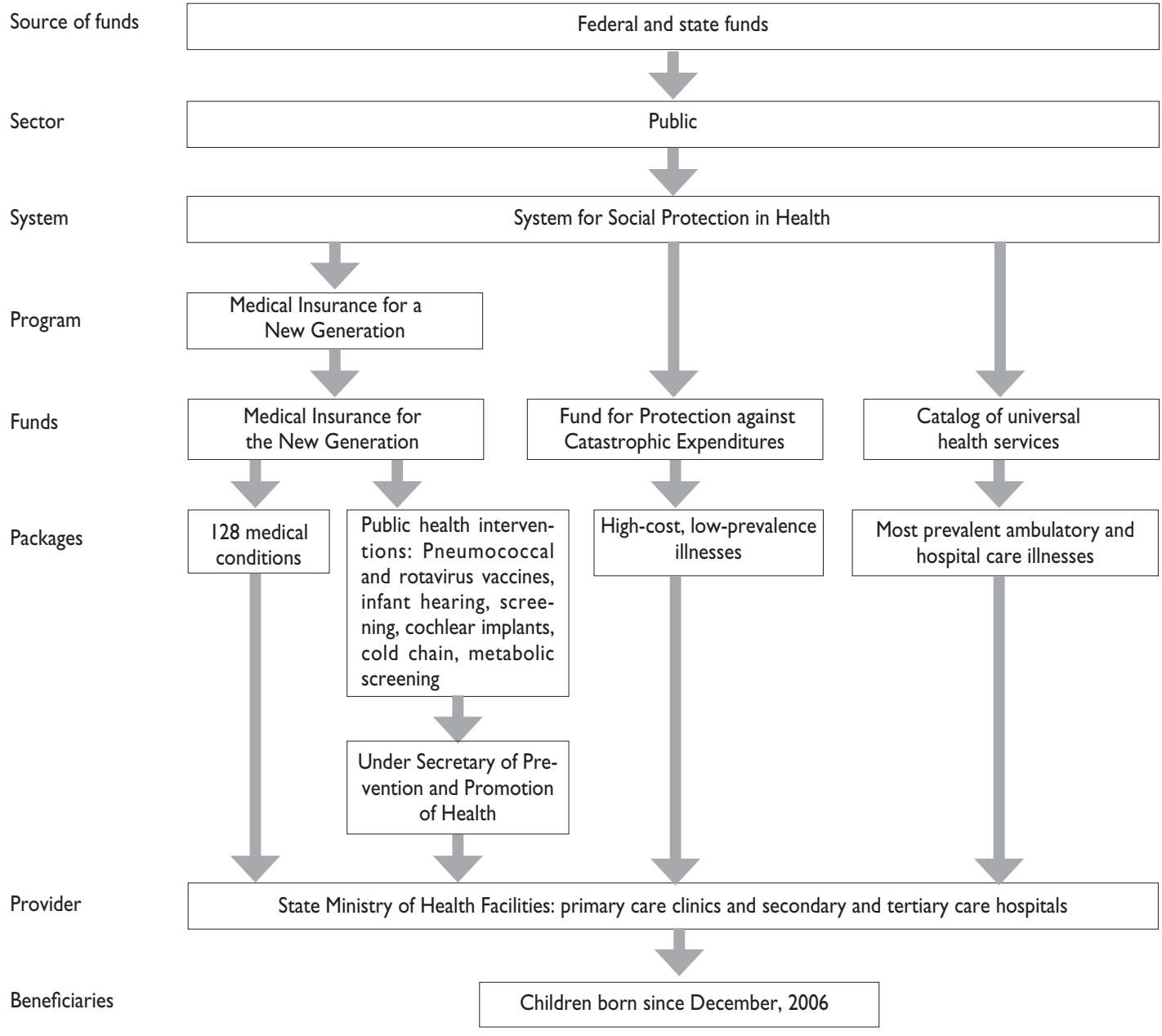

Figure I. Framework of the Medical Insurance for the New Generation 
the most common ambulatory and hospital care medical conditions. The rules of operation clearly define which are the interventions of these three funds. ${ }^{43}$

SMNG aims to strengthen the decentralized $\mathrm{MoH}$ capability of the Mexican states to facilitate access to and to provide health care. The program does not affect or duplicate other government programs and interventions regarding the design, benefits, provided support and target population. If the $\mathrm{MoH}$ services are unavailable, SMNG will make health care accessible to the children, through agreements reached between SMNG and social security institutions and private providers.

Initially, the strategy of SMNG was to include all children younger than five years that were born after December 2006, and who were not affiliated with social security. It is expected that SMNG will cover all children without social security by 2012. Affiliation with SMNG is voluntary and offered after the child is born. Once the child is affiliated, the other members of the family must be affiliated with Seguro Popular.

The objectives of SMNG are:

- To reduce the incidence of diseases and disability

- To promote preventive care and ensure comprehensive coverage of health care.

- To reduce neonatal mortality

- To reduce morbidity and mortality of infant and preschool children

- To foster healthy growth and development.

- To provide health services, including medications that respond to the epidemiological profile, health needs and demands for health care.

- To prevent the impoverishment of families derived from expenditures on health care for children under 5 years

Its rules of operation state that SMNG should be monitored and evaluated continuously. The evaluation is conceptualized as a continuous and systematic process that, along with monitoring activities, will allow identification of its achievements and limitations. The evidence gathered through the evaluation would lead to adjustments and implementation of interventions aimed at improving SMNG performance.

Improvement of child health has driven policies that are operationalized in a number of programs and interventions. It has been criticized that most programs are focused on medical aspects, such as preventive and curative care to reduce morbidity and mortality and other environmental and social factors are being neglected. ${ }^{44}$ In Mexico there are several programs addressing social needs of children and their mothers, such as the program Oportunidades which is an anti-poverty program focused in poor rural and urban families. This is a conditional cash-transfer program aimed at improving societal conditions and decrease poverty. The program has proven to be successful in promoting better growth of children. ${ }^{45,46}$

The increase in funds SMNG is a program that can contribute to decrease the burden of disease in children under five years old and alleviate health expenses of families who must care for sick children. SMNG has the legal, financial and organizational mechanisms that will facilitate its operation. The evaluation of the program in terms of the achievement of its objectives will be central groundwork to developing evidence-based public policies aimed at improving the health of Mexican children and would provide valuable lessons for other healthcare systems aimed at developing or strengthening their systems for social protection of health.

\section{Acknowledgment}

The realization of this evaluation was achieved thanks to the financial support from the Sistema Nacional de Protección en Salud and the Seguro Médico para una Nueva Generación.

Declaration of conflict of interests: The authors declare not to have conflict of interests.

\section{References}

I. UNICEF. The State of the World's Children. Maternal and Newborn Health. New York: United Nation's Children's Fund; 2008.

2. Secretaría de Salud. Rendición de Cuentas en Salud 2009. México: Secretaría de Salud; 2010.

3. Instituto Nacional de Estadística y Geografía. Censo de Población y Vivienda 2010. Consulta interactiva de datos. [Accessed September 27, $20 \mathrm{II}$ ]. Available at: http://www.inegi.org.mx/sistemas/olap/proyectos/bd/ consulta.asp? $p=|7| \mid$ 8\&c=27769\&s=est\#.

4. Organization for Economic Cooperation and Development. Reviews of Health Systems Mexico. Paris: OECD 2005.

5. UNICEF. Vigía de los derechos de la niñez mexicana. Los primeros pasos. No I, abril 2005. [Accessed 8 of August, 20I0]. Available at: http:// www.unicef.org/mexico/spanish/mx_resources_vigia_l.pdf.

6. Consejo Nacional de Población. Proyecciones de la Población de México, 2000-2050. México; CONAPO: 2002.

7. Secretaría de Salud. Dirección General de Información en Salud. Proyecciones de población 2005-2030. México; Consejo Nacional de Población 2006: SSA/DGIS: 2010

8. Haas S. Trajectories of functional health: The 'long arm' of childhood health and socioeconomic factors. Soc Sci Med 2007;66(4):849-86I.

9. Ávila F, Shamah T. Diagnóstico de la magnitud de la desnutrición infantil en México. En: Zuñiga E. México ante los desafíos del milenio. México; CONAPO: 2005.

10. Rivera J, Shamah T, Villalpando S, González de Cossío T, Hernández B, Sepúlveda B. Encuesta Nacional de Nutrición I999; Estado Nutricio 
de Niños y Mujeres en México. México; Instituto Nacional de Salud Pública:1999.

II. Oláiz-Fernández G, Rivera-Dommarco J, Shama-Levy T, VillalpandoHernández S, Hernández-Ávila M, Sepúlveda-Amor J. Encuesta nacional de salud y nutrición 2006. Cuernavaca, México: Instituto Nacional de Salud Pública, 2006.

12. Instituto Mexicano del Seguro Social. Encuesta nacional de coberturas. Síntesis 2003-2006. México: IMSS; 2007.

13. Gupta N, Goel K, Shah P, Misra A. Childhood obesity in developing countries: epidemiology, determinants and prevention. Endocr Rev 20I2;33(I):48-70.

14. Guo SS, Wu W, Chumlea WC, Roche A. Predicting overweight and obesity in adulthood from body mass index values in childhood and adolescence. Am J Clin Nutr 2002;76:653-658.

15. World Health Organization. Obesity, preventing and managing the global epidemic. Geneva: World Health Organization; 1997.

16. Flores-Huerta S, Martínez H. Prácticas de alimentación, estado de nutrición y cuidados a la salud en niños menores de 2 años en México. México: Instituto Mexicano del Seguro Social; 2004.

17. Flores-Huerta S, Pérez-Cuevas R, Garduño J, Reyes H, Rodríguez $\mathrm{E}$, Muñoz $\mathrm{O}$. Una mirada desde los servicios de salud a la nutrición de la niñez mexicana. II. Problemas emergentes: sobrepeso y obesidad. Bol Med Hosp Infan Mex. 2007;64:399-407.

18. Lozoff B, Jimenez E, Wolf A. Long-term developmental outcome of infants with iron deficiency. N Engl J Med. 199I; 325: 687-94.

19. Grantham-McGregor S, Ani C. A review of studies on the effect of iron deficiency on cognitive development in children. J Nutr. 200I; I3।: 649S-668S

20. Keusch G, Fontaine O, Bhargava A, Boschi- Pinto C, Bhutta Z, Gotuzzo E, et al. In: Diarrheal Diseases. Jamison D, Breman J, Measham A, Alleyne G, Claeson M, Evans D, et al. Disease Control Priorities in Developing Countries. Washington; World Bank and Oxford University Press: 2006. Ch 19. Pp:37I-388.

2I. Richardson V, Hernández J, Quintanar M, Esparza M, Johnson B, Gómez $\mathrm{C}$, et al. Effect of rotavirus vaccination on death from childhood diarrhea in Mexico. N Eng J Med 2010;362:299-305.

22. Valencia-Mendoza A, Bertozzi S, Gutierrez JP, Itzler R. Costeffectiveness of introducing a rotavirus vaccine in developing countries: The case of Mexico. BMC Infectious Diseases 2008, 8:103 doi: I0.I I86/I47|-2334-8-I03.

23. Simoes E, Cherian T, Chow J, Shahid- Salles S, Laxminarayan R, Jacob JT. Acute Respiratory Infections in Children. In: Jamison D, Breman J, Measham A, Alleyne G, Claeson M, Evans D, et al. Disease Control Priorities in Developing Countries. Washington; World Bank and Oxford University Press: 2006. Ch 25. Pp:483-498.

24. World Health Organization. World Health Report 2000: Health Systems: improving performance. Geneva; WHO: 2000.

25. Commission on Social Determinants of Health. Closing the gap in a generation: health equity through action on the social determinants of health. Geneva; World Health Organization: 2008.

26. Barraza-Lloréns M, Bertozzi S, González-Pier E, Gutiérrez J. Addressing Inequity In Health And Health Care In Mexico. Health Affairs. 2002;2I(3):47-57.

27. Knaul F, Arreola H, Borja Ch, Méndez O, Torres A. El Sistema de Protección Social en Salud de México: efectos potenciales sobre la justicia financiera y los gastos catastróficos de los hogares. In: Knaul F, Nigenda G: Caleidoscopio de la Salud. De la investigación a las políticas y de las políticas a la acción". México; FUNSALUD: 2003.
28. Knaul FM, Arreola-Ornelas H, Méndez-Carniado O, Bryson-Cahn C, Barofsky J, Maguire R, Miranda M, Sesma S. Las evidencias benefician al sistema de salud: reforma para remediar el gasto catastrófico $y$ empobrecedor en salud en México. Salud Publica Mex 2007;49 supl I:S70-S87.

29. Braveman P, Gruskin S. Defining equity in health. J. Epidemiol. Community Health 2003;57;254-258.

30. Secretaría de Salud. Plan Nacional de Salud 2007-2012. Secretaría de Salud México, 2009.

31. Aday LA, Andersen RM. Equity of access to medical care: a conceptual and empirical overview. Med Care. 1981;19(12):4-27. 32. Frenk J. The concept and measurement of accessibility. In: White KL. Health services research: an anthology. Washington, DC: Pan American Health Organization; Scientific Pub. No. 534, 1992:842-55.

33. Hall A, Lemak Ch, Steingraber H, Stephen Shaffer S.Expanding the Definition of Access: It Isn't Just About Health Insurance. J Health Care for the Poor and Underserved. 2008; 19: 625-637.

34. Gómez-Dantés O, Gómez-Jáuregui J, Inclán C. La equidad y la imparcialidad en la reforma del sistema mexicano de salud. Salud Publica Mex 2004;46:399-416.

35. Subsecretaría de Prevención y Promoción de la Salud. Programa de Acción Específico 2007-2012 Arranque Parejo en la Vida. Secretaría de Salud, México 2007.

36. Institute of Medicine: Crossing the Quality Chasm: A New Health System for the 21 st Century. Washington DC: National Academy Press; 2001.

37. Kelley E, Hurst J. Health Care Quality Indicators Project Conceptual Framework Paper. OECD Health Working Papers NO. 23. DELSA/HEA/ WD/HWP(2006)3 Paris: OECD, 2006

38. Organization for Economic Cooperation and Development. Health at a Glance 2009: OECD indicators. Paris: OECD; 2009

39. Reyes H, Pérez-Cuevas R, Salmerón J, Tomé P, Guiscafré H, Gutiérrez $G$. Infant mortality due to acute respiratory infections: the influence of primary care processes. Health Policy Plan 1997; 12(3): 214-223 40. Gutiérrez G, Reyes H, Fernández, Pérez-Cuevas R, Guiscafré H. Impacto de los servicios de salud, el saneamiento y la alfabetización en la mortalidad de menores de cinco años. Salud Publica Mex 1999; 4I:368-375. 4I. Knaul F, Frenk J. Health Insurance In Mexico: Achieving Universal Coverage Through Structural Reform. Health Affairs. 2005; 24(6): I4671476.

42. INEGI. Encuesta Nacional de Ingreso Gasto de los Hogares ENIGH 2008. México: INEGl; 2009.

43. Diario Oficial. Acuerdo por el que se emiten las Reglas de Operación del Programa Seguro Médico para una Nueva Generación para el ejercicio fiscal 20II. Mexico. Diario Oficial. Miercoles 29 de diciembre de 2010.

44. Ehiri J, Prowse J. Child health promotion in developing countries: the case for integration of environmental and social interventions? Health Policy and Planning 1999; I4(I): I-10

45. Leroy JL, García-Guerra A, García R, Dominguez C, Rivera J, Neufeld LM. The Oportunidades Program Increases the Linear Growth of Children Enrolled at Young Ages in Urban Mexico. J Nutr 2008; 138:793-798. 46. Fernald LCH, Gertler P, Neufeld LM. The Importance of Cash in Conditional Cash Transfer Programs for Child Health, Growth and Development: An Analysis of Mexico's Oportunidades. Lancet. 2008; 37I: 828-837. 